

\title{
MONEY LAUNDERING AND CENTRAL BANK GOVERNANCE IN THE EUROPEAN UNION
}

\author{
Panicos Demetriades* \\ Radosveta Vassileva**
}

Dirty money is often a by-product or a symptom of political corruption in the jurisdictions in which it originates. It can also spread corruption and erode democracy on its journey to its final destination. This typically involves multiple jurisdictions and is the reason why it is so hard to detect. Recently, a series of money laundering scandals have highlighted weaknesses in the anti-money laundering and counterterrorist financing (AML/CFT) framework of the European Union (EU), the implementation of which remains the responsibility of member states. The paper argues that EU's defences against money laundering have been weakened partly reflecting a little-known erosion in the independence of member state central banks which are often the AML supervisors. It puts forward a number of new proposals to strengthen governance and AML/CFT implementation in the EU.

\footnotetext{
* Professor of Financial Economics at the University of Leicester. Former Governor of the Central Bank of Cyprus and member of the European Central Bank_ 3 May 2012-10 April 2014), pd28@leicester.ac.uk; We are thankful to Dr George Georgiou, the participants at the conference dedicated to 'The Era of Disintegration' at Erasmus University, the anonymous reviewers and the special editors of this issue of the Journal of International Economic Law for helpful comments on earlier drafts. Naturally all remaining errors are our own. Demetriades gratefully acknowledges financial support from DFID-ESRC award reference ES/No13344/2.

**PhD in Law, University College London, radosveta.vassileva@ucl.ac.uk
} 


\section{Introduction}

Central banks were initially set up to issue and manage the currency and to offer banking services to governments - often helping them to finance their war efforts. However, their responsibilities have evolved over time to overseeing commercial banks and other financial institutions and offering lender of last resort services. ${ }^{1}$ Nowadays, the primary role of central banks is to deliver low and stable inflation, through the use of monetary policy instruments such as short-term interest rates. ${ }^{2}$ Most, if not all, central banks have responsibilities that include promoting conditions of financial stability. In many countries these responsibilities include micro-prudential supervision of individual financial institutions, as well as macro-prudential regulation and supervision intended to address system-wide risk. ${ }^{3}$ Often, alongside prudential supervision, central banks are also responsible for overseeing banks' adherence to anti-money laundering and counter-terrorist financing (AML/CFT) legislation. ${ }^{4}$ The majority of central banks in the European Union (EU) do, in fact, have AML supervision responsibilities. It is this little-known central bank responsibility that is the focus of the current paper against the context of weakening central bank independence, which is neither well known nor analysed in detail.

1

Charles Goodhart, The Evolution of Central Banks (Cambridge: MIT Press, 1988) 1-218; Michael Bordo, 'A Brief History of Central Banks', Federal Reserve Bank of Cleveland, https://www.clevelandfed.org/en/newsroom-andevents/publications/economic-commentary/economic-commentary-archives/2007economic-commentaries/ec-20071201-a-brief-history-of-central-banks.aspx (accessed 25 March 2020).

2

Panicos Demetriades, Central Bank Independence and the Future of the Euro (Newcastle: Agenda Publishing, 2019) 1-13.

3

Claudio Borio and William White, 'Wither Monetary and Financial Stability? The Implications of Evolving Policy Regimes', BIS Working Papers (2004), at 147; Claudio Borio and Philip Lowe, 'Asset Prices, Financial and Monetary Stability: Exploring the Nexus', BIS Working Papers (2002), at 114.

4

For brevity, the abbreviation AML in this paper should be taken to also include CFT. 
Although central bank legal frameworks vary from country to country, most central banks enjoy — in theory — independence from their respective governments. Levels of central bank independence, however, have varied considerably over time and across countries. ${ }^{5}$ The European System of Central Banks (ESCB) is, by design, among the most independent in the world, in that some of its independence safeguards are enshrined in Article 130 of the Treaty on the Functioning of the European Union (TFEU). ${ }^{6}$ This key provision cannot easily be changed because a revision in EU Treaties requires unanimity among all member states pursuant to Article 48(6) of the Treaty on European Union (TEU). These safeguards are designed to protect the personal independence of central bank governors, the financial independence of central banks, as well as the operational independence of central bank decisions.

The scope of this independence is, however, limited. To start with, only central bank governors' personal independence is protected by the TFEU. Central bank governors are appointed for a minimum five-year term and can only be removed from office on grounds of incapacity or serious misconduct. ${ }^{7}$ EU Treaties, however, are silent on the independence of deputy governors or members of governing bodies of national central banks. Moreover, tasks other than monetary policy, such as banking supervision, are in a somewhat grey area and open to legal interpretation. ${ }^{8}$

5

See Demetriades, Central Bank Independence and the Future of the Euro, above n 2, at 15-29; Sylvester C.W Eijffinger and Jakob De Haan, 'The Political Economy of Central Bank Independence', Special Papers in International Economics, No. 19, International Finance Section, Princeton University (1996), at 22-28; Alberto Alesina and Lawrence H. Summers, 'Central Bank Independence and Macroeconomic Performance: Some Comparative Evidence', 25(2) Journal of Money, Credit and Banking 151 (1993), at 151-162.

6

The article explicitly stipulates that ' $[\mathrm{w}] \mathrm{hen}$ exercising the powers and carrying out the tasks and duties conferred upon them by the Treaties and the Statute of the ESCB and of the ECB, neither the European Central Bank, nor a national central bank, nor any member of their decision-making bodies shall seek or take instructions from Union institutions, bodies, offices or agencies, from any government of a Member State or from any other body'.

7

Article 14 of Protocol (no 4) on the Statute of the European System of Central Banks and the European Central Bank, annexed to the TEU.

8

Ignazio Angeloni, 'Supervisory Independence' (Speech at the ECB Colloquium 'Challenges for Supervisors and Central Banks', Frankfurt, 22 March 2018), 
The European Central Bank (ECB) itself interprets its own independence rather narrowly. ${ }^{9}$ However, it has been contended that the EU Treaties cover all the tasks and functions of the ECB. ${ }^{10}$

Be that as it may, there is by now considerable evidence that even the independence of central bank governors has not withstood the test of time. There are case studies which suggest that governors were compelled to resign following actions they took to deal with failing banks or disagreements with their respective governments. ${ }^{11}$ Additionally, there are examples illustrating that central banks elsewhere are changing their behaviour to better align themselves with their respective governments. ${ }^{12}$ Moreover, ongoing litigation under the Racketeer Influenced and Corrupt Organizations Act, a United States (US) federal act, at the New York Southern District Court in which Bulgaria's central bank (the Bulgarian National Bank) and a Bulgarian politician are among the defendants raises concerns that central banks do not take decisions independently. ${ }^{13}$ More importantly, when it

https://www.bankingsupervision.europa.eu/press/speeches/date/2019/html/ssm.sp190 322 c231d57793.en.html, accessed 26 March 2020.

This may also be changing over time if the evolving views of ECB Executive Board members are any indication. See Lorenzo Bini Smaghi, 'Central Bank Independence: From Theory to Practice', 14(4) European Law Journal (2008) 446-460. See also Yves Mersch, 'Central Bank Independence Revisited' (Keynote address at the Symposium on Building the Financial System of the $21^{\text {st }}$ century: An Agenda for Europe and the United States, Frankfurt, 30 March 2017) https://www.ecb.europa.eu/press/key/date/2017/html/sp170330.en.html, accessed 27 March 2020.

10

Rosa M. Lastra, 'The Evolution of the European Central Bank', 35(5) Fordham International Law Journal (2012), at 1260-1281.

11

Panicos Demetriades, A Diary of a Euro Area Banking Crisis: Lessons for Bank Recovery and Resolution (Cham: Palgrave-Macmillan, 2017) 157-159; Demetriades, Central Bank Independence and the Future of the Euro, above n 2, 107 110.

12

Demetriades, Central Bank Independence and the Future of the Euro, above n 2, 10-13.

13

US, New York Southern District Court, Rudersdal, EOOD v. Harris (1:18cv-11072), https://www.courtlistener.com/docket/8288935/rudersdal-eood-vharris/?fbclid=IwAR0qWHS1EvMSLb3U4FEL3XznLxTsW4M2I3a8oOzwShA3Chn ROfoWOC_jQm8, accessed 8 April 2020; Claimants allege that the central bank engaged in fraud to serve the private interests of a politician. 
comes to the fight against money-laundering, central banks' governing bodies — that are less independent than their governors - may come under political pressure to turn a blind eye to law violations. Such pressure can be exerted from their respective governments, political parties or individual politicians with business ties, ${ }^{14}$ special interest groups, such as powerful banks, law and accountancy firms that benefit from offering services to wealthy investors, etc. Although such pressure may sometimes be disguised as a legitimate attempt to reduce 'red tape' and create a more friendly business environment, it may result - intentionally or not - in reduced defences against money laundering.

The consequences of weaker money laundering defences do not, however, remain within national boundaries. Once proceeds of crime or, more generally, money acquired illegally enter the single financial market, they can travel freely throughout the EU. The single financial market is, therefore, as strong as its weakest link. Indeed, recent scandals in which there were allegations about money laundering, which we would examine below, have shown that dirty money typically exploits weaknesses to enter. According to a recent report by the UK Parliament, while the scale of economic crime in the United Kingdom (UK) is 'uncertain', '[i]t seems that it can reasonably be said to run into the tens of billions of pounds, and probably the hundreds of billions'. ${ }^{15}$ The risks emanating from such large volumes of money cannot be underestimated and, in fact, may either contribute to the process of disintegration of the EU, or at least accompany disintegration episodes, as we argue below. Money laundering, of course, is not just a problem for the UK. Because of the limited international media attention devoted to smaller or newer member states, it is often forgotten that they could be the final destinations of dirty money too. Moreover, money laundering may involve several jurisdictions and smaller or newer member states may be the place

Such brokerage is typical of captured states, which are traditionally defined as states in which public power is primarily exercised for private gain. For a discussion on captured states in the EU, see Abby Innes, 'The Political Economy of Captured States', (52)1 Journal of Common Market Studies (2014), at 88-104. 15

'Economic Crime - Anti-Money Laundering Supervision and Sanctions Implementations', Treasury Committee,

https://publications.parliament.uk/pa/cm201719/cmselect/cmtreasy/2010/2010 09.htm\#_idTextAnchor083 8 March 2019, accessed 27 March 2020. 
where dirty money first enters the single market. States which have political ties or geographic proximity to Russia seem particularly vulnerable. ${ }^{16}$

First, this article explores the possible relationship between European disintegration and illicit financial flows. Then, it critically analyses the AML framework to showcase why central banks usually have an important role in the fight against money laundering, which is often ignored. Finally, it explores how fragile central bank independence and related AML supervision weaknesses may compromise the goals of AML legislation and makes concrete recommendations how to remedy these deficiencies.

\section{European Disintegration and Illicit Financial Flows}

It has been asserted that ' $[\mathrm{s}]$ chemes for European integration are almost as old as the idea of Europe as a distinct political and cultural entity and much older than the conception of Europe of nation states' ${ }^{17}$ It has also been stressed that 'European integration has always meant different things to different people'. ${ }^{18}$ For instance, those with left-wing views may see regulation as an important pillar of integration while those with right-wing views may regard regulation as a threat to integration. The EU is surely the most successful integration project in Europe ${ }^{19}$ and, unsurprisingly, it is often treated as synonymous to European integration. The Oxford Dictionary of Contemporary World History, for example, defines European

16 See Chris Raggett, 'Networks of Impunity: Corruption and European Foreign Policy', European Council on Foreign Relations Policy Paper, https://www.ecfr.eu/publications/summary/networks_of_impunity_corruption_and_eu ropean_foreign_policy 2020, accessed 9 April 2020.

17

Robert Bideleux, 'Introduction: European Integration and Disintegration', in Robert Bideleux and Richard Taylor (eds), European Integration and Disintegration: East and West (London: Routledge, 1996) 1.

18

Ibid, at 2.

19

It has been referred to as 'the only instance of large-scale political integration in recent world history'. Hans Volaard, 'Explaining European Disintegration', 52(5) Journal of Common Market Studies 1142 (2014), at 1142. 
integration as 'the formation of European states into the world's closest regional association, which has assumed many of the characteristics of statehood' ${ }^{20}$

Yet, it has been emphasised that forces of integration and disintegration traditionally coexist. ${ }^{21}$ The EU indeed has been haunted by the tension between these forces since its establishment. Opt-out mechanisms, which permit differentiated integration, serve as illustrations of this friction. ${ }^{22}$ In turn, there is debate on whether differentiated integration induces a 'positive dynamic of integration', a 'negative dynamic of disintegration', or to 'lasting divisions within [the EU]'. ${ }^{23}$ Recent disintegration episodes, which have drawn the attention of scholars, include the Eurocrisis, the migration crisis, Brexit, and the rise of illiberalism in member states like Poland and Hungary. ${ }^{24}$ In fact, there are pessimists who have gone as far as discussing the likelihood of the EU disintegrating as an entity. ${ }^{25}$

While illicit financial flows are traditionally perceived as a problem affecting mostly developing countries, ${ }^{26}$ they may be a cause or a symptom of European

Christopher Riches and Jan Palmowski, Oxford Dictionary of Contemporary World History, $5^{\text {th }}$ edn (Oxford: Oxford University Press, 2019).

Robert Bideleux, above n 17, at 5.

Some EU member states opt out of certain policies in order not to prevent others from moving towards further integration. For instance, the UK opted out from moving to the third stage of the Economic and Monetary Union. See Protocol (No 25) on certain provisions relating to the United Kingdom of Great Britain and Northern Ireland (1992) annexed to the TEU.

23

Alkuin Kölliker, 'Bringing Together or Driving Apart the Union: Towards a Theory of Differentiated Integration', 24 West European Politics 125 (2001) 126; See also Alkuin Kölliker, Flexibility and European Unification: The Logic of Differentiated Integration (Oxford: Rowman and Littlefield 2006); Jan-Emmanuel de Neve, 'The European Onion? How Differentiated Integration is Reshaping the EU', 29(4) Journal of European Integration (2007), at 503-521.

24

Liesbet Hooghe and Gary Marks, 'Grand Theories of European Integration in the Twenty-First Century', (26)8 Journal of European Public Policy (2019) 11131133; Douglas Webber, European Disintegration? The Policy of Crisis in the European Union (London: Macmillan, 2019) 56-206; See also the contributions of Massimo D'Antoni and Menelaos Markakis in this issue. 25

Webber, above n 24, 19-55; Ivan Krastev, 'A Fraying Union?', 23(4) Journal of Democracy (2012) 23-30. 
disintegration episodes and processes, too. A recent policy brief by the World Bank defines illicit financial flows as 'money illegally earned, transferred, or used that crosses borders' and identifies three main types: 1) transferring clean money for an illegal purpose, such as financing crime; 2) illegal transfers (tax evasion); 3) legal transfers of funds which are illegal. ${ }^{27}$

The first type has also been referred to as 'money dirtying' (the opposite of money laundering). ${ }^{28}$ Traditionally, this type is associated with the financing of terrorism and extremism. However, it has also prompted analysts to propose the term 'political money laundering' to identify cases in which suspicious money (not necessarily money from proven illegal activities) is used for election interference or other activity threatening democratic values. ${ }^{29}$ It is known, for instance, that the driving force behind the 'Leave the EU' campaign, which eventually led to Brexit and thus contributed to disintegration in the EU, was the UK Independence Party (UKIP), a right-wing party considered to be populist. ${ }^{30}$ UKIP built momentum by engaging in rhetoric against the EU and its values. ${ }^{31}$ There is indirect evidence that the 'Leave'

See Organisation for Economic Co-operation and Development, Illicit Financial Flows from Developing Countries: Measuring OECD Responses (Paris: OECD Publishing, 2014).

27

World Bank, 'Illicit Financial Flows (IFFs)', 7 July 2017, https://www.worldbank.org/en/topic/financialsector/brief/illicit-financial-flows-iffs, accessed 25 March 2020.

28

Brigitte Unger, 'Money Laundering Regulation: From Al Capone to Al Qaeda', in Brigitte Unger and Daan van der Linde (eds), Research Handbook on Money Laundering (Cheltenham: Edward Elgar, 2013) 21.

29

Neil Barnette and Alastair Sloan, 'Democracy in the Crosshairs: How Political Money Laundering Threatens the Democratic Process', Atlantic Council Eurasia Center, https://atlanticcouncil.org/in-depth-research-reports/report/democracy-in-thecrosshairs-how-political-money-laundering-threatens-the-democratic-process/ 2018, accessed 26 March 2020.

30

Ben Pitcher, 'Racism and Brexit: Notes Towards an Antiracist Populism', 42(14) Ethnic and Racial Studies (2019), at 2490-2509; Darren Kelsey, 'Hero Mythology and Right-Wing Populism: A Discourse-Mythological Case Study of Nigel Farage in the Mail Online', 17(8) Journalism Studies (2016), at 971-988. 
campaign was financed by Russia. ${ }^{32}$ Moreover, in 2014, le Front National, a French extreme right party, received a loan from an obscure Russian bank. ${ }^{33}$ It may not be accidental that its leader Marine le Pen called for Frexit, after UKIP's success. ${ }^{34}$

The second and the third type of illicit financial flows may shade into each other. While the definitions of money laundering in national criminal laws may diverge - below we will see that the EU introduced a common, imperfect definition relatively late - it is accepted that money laundering covers the cases in which one intentionally conceals the origin of proceeds of crime. ${ }^{35}$ Tax evasion, which the World Bank has given as an example of an illegal transfer, is also a crime. Moreover, money laundering does not necessarily involve cross-border transactions. The precision of definitions and nuances aside, it is the second and the third type of illicit financial flows which may be the by-product of corruption and rule of law decay not only outside of the EU, but also within the EU. In principle, empirical research has shown the close link between corruption and money laundering which, arguably, implies that '[the] prevalence of one of these offences in a country usually signifies the prevalence of the other'. ${ }^{36}$ This threat to, or even attack against, EU values can surely contribute to the process of European disintegration. ${ }^{37}$

See Ceri Hughes, 'It's the EU Immigrants Stupid! UKIP's Core-Issue and Populist Rhetoric on the Road to Brexit', 34(3) European Journal of Communication (2019) 248-266.

32

Ewan McGaughey, 'The Extent of Russian-Backed Fraud Means the Referendum is Invalid', London School of Economics Blog,

https://blogs.lse.ac.uk/brexit/2018/11/14/the-extent-of-russian-backed-fraudmeans-the-referendum-is-invalid/ 2018, accessed 25 March 2020.

33

Gabriel Gatehouse, 'Marine Le Pen: Who's Funding France's Far Right?', $B B C$, 3 April 2017. https://www.bbc.com/news/world-europe-39478066, accessed 25 March 2020.

34

Michael Stothard, 'Could France's Marine Le Pen deliver Frexit?', Financial Times, 14 March 2017.

35

A publication by the International Monetary Fund specifies: 'Money laundering requires an underlying, primary, profit-making crime (such as corruption, drug trafficking, market manipulation, fraud, tax evasion), along with the intent to conceal the proceeds of the crime or to further the criminal enterprise', https://www.imf.org/external/np/leg/amlcft/eng/, accessed 24 March 2020. 
For instance, the rise of illiberalism in Poland and Hungary can be considered an important episode of European disintegration. ${ }^{38}$ Currently, both states are subjected to infringement proceedings under Article 7 TEU for breaching Article 2 TEU. While Bulgaria does not face infringement proceedings for breaching Article 2 TEU at this stage, it is considered the most corrupt EU member ${ }^{39}$ where the rule of law is undermined. ${ }^{40}$ Unsurprisingly, there are rising suspicions that these regimes launder proceeds of illegal activities carried out on their own territory. Critics of Hungarian Prime Minister Viktor Orbán assert that the Hungarian Parliament passed 'a mass of custom-tailored laws that mostly served as a framework for any subsequent manipulation, as well as laws that generally support the functioning of the mechanisms of state corruption', including a law facilitating money laundering. ${ }^{41}$ They also allege that a circle of businessmen close to Orbán 'launder[s] illegally gained public funds simply by paying themselves huge dividends'. ${ }^{42}$ Relatedly, in

Norman Mugarura, 'Uncoupling the Relationship between Corruption and Money Laundering Crimes', 24(1) Journal of Financial Regulation and Compliance 74 (2016), at 74.

37 Article 2 TEU stipulates that the EU is 'founded on the values of respect for human dignity, freedom, democracy, equality, the rule of law and respect for human rights, including the rights of persons belonging to minorities'.

On the concrete challenges faced by these member states, see Laurent Pech and Kim Lane Scheppele, 'Illiberalism Within: Rule of Law Backsliding in the EU', 19 Cambridge Yearbook of European Legal Studies (2017), at 3-47. 39

The Corruption Perceptions Index by Transparency International traditionally ranks Bulgaria as the most corrupt EU member. The latest one is available here: https://www.transparency.org/cpi2019. 40

The Rule of Law Index by the World Justice Project has given Bulgaria and Hungary the lowest scores among EU members,

https://worldjusticeproject.org/sites/default/files/documents/WJP-ROLI-2020Online_0.pdf, accessed 25 March 2020; For an analysis of the concrete changes vis-àvis the rule of law, see Radosveta Vassileva, 'So Why Don't We Just Call the Whole Rule of Law Thing Off, Then? On Tomatoes, Tomahtoes, and Bulgaria's Cooperation and Verification Mechanism', Verfassungsblog, https://verfassungsblog.de/so-whydont-we-just-call-the-whole-rule-of-law-thing-off-then/, accessed 25 March 2020. 41

Bálint Magyar, Post-Communist Mafia State: The Case of Hungary (Budapest: Central European University Press, 2016) 264. 
early 2020, Spanish authorities confirmed that they were investigating the Prime Minister of Bulgaria Boyko Borissov for alleged money laundering since 2013 - the facts, as revealed by El Periodico, which initially broke the story, will illustrate a failure of AML protocols in several member states (at least Bulgaria, Cyprus, and Spain) if confirmed because the inquiry was launched only after a complaint by a civil pressure group. $^{43}$

Once autocratic regimes in the EU purposefully weaken AML governance, it makes it easier for others to exploit these loopholes as well. For instance, it does not seem accidental that in 2019, Bulgaria was shaken by a money laundering scandal involving funds transferred from Venezuela through Russia - Bulgarian authorities reacted only after they were prompted by US authorities. ${ }^{44}$ In parallel, laundering of proceeds from non-EU kleptocratic regimes may also threaten the rule of law in EU member states, which have a higher regard for the rule of law, because they 'risk importing practices common to life under kleptocratic regimes'. ${ }^{45}$ Below we will examine cases which seem to illustrate this phenomenon.

Now that we have scoped out the possible relationship between money laundering and the question of European disintegration, we turn our attention to the AML framework to showcase why the independence of AML regulators, including central banks, is of key importance.

\section{The AML Framework and the EU}

Bálint Magyar and Balint Madlovics, 'Hungary's Mafia State Fights for Impunity', Balkan Insight, https://balkaninsight.com/2019/06/21/hungarys-mafiastate-fights-for-impunity/2019, accessed 25 March 2020.

43

'Spanish Police Confirm Investigation into Bulgarian PM Borissov', Sofia Globe, https://sofiaglobe.com/2020/02/21/spanish-police-confirm-investigation-intobulgarian-pm-borissov-reports/, accessed 26 March 2020; Luis Rendueles and Vanesa Lozano, 'Una investigación por blanqueo de dinero en Barcelona apunta al primer ministro de Bulgaria', El Periodico https://www.elperiodico.com/es/politica/20200221/primer-ministro-bulgaria-mossosinvestigacion-blanqueo-78482742020, accessed 26 March 2020.

44 Sandrine Amiel, 'Venezuela's State Oil Firm "Transferred Millions of Euros to Bulgarian Bank Accounts"', Euronews, https://www.euronews.com/2019/02/14/bulgaria-investigates-suspected-money-

laundering-by-venezuela-s-state-oil-company, accessed 4 April 2020.

45 See Chris Raggett, above n 16. 
The last three decades saw the development of a complex AML framework both on an international and an EU level. ${ }^{46}$ The Financial Action Task Force (FATF) has been referred to as 'the single most influential international body in terms of formulation of Anti-Money Laundering policy and mobilization of global awareness of the complex issues involved in countering this sophisticated form of criminality'. ${ }^{47}$ Set up in 1989, it has 37 member jurisdictions, 15 of which are EU members, and two regional organisation members: one of them is the European Commission. ${ }^{48}$ The Committee of Experts on the Evaluation of Anti-Money Laundering Measures and the Financing of Terrorism (MONEYVAL), a permanent monitoring body of the Council of Europe established in 1997, is an associate member of FATF. FATF has so far issued forty non-binding recommendations. ${ }^{49}$ In parallel, there are binding international instruments by international organisations. ${ }^{50}$ FAFT standards and international conventions have influenced EU's response in this area. ${ }^{51}$ Historically, the EU has

For a historic overview of the most important initiatives, see Wouter $\mathrm{H}$. Muller, Christian, H. Kalin and John G. Goldsworth (eds), Anti-Money Laundering: International Law and Practice (Chichester: Wiley \& Sons, 2007) 35-105; Sue Turner and Jonathan Bainbridge, 'An Anti-Money Laundering Timeline and the Relentless Regulatory Response', 82(3) Journal of Criminal Law 215 (2018), at 216-218. 47

William C. Gilmore, Dirty Money: The Evolution of International Measures to Counter Money Laundering and the Financing of Terrorism, $4^{\text {th }}$ edn (Strasbourg: Council of Europe Publishing, 2011), 91. 48

See 'Members and Observers' list, https://www.fatfgafi.org/about/membersandobservers/, accessed 25 March 2020. 49

The latest version of 2012 is available on their website: www.fatfgafi.org/recommendations.

50

For instance, United Nations Convention against Illicit Traffic in Narcotic Drugs and Psychotropic Substances, done in Vienna, 20 December 1988, E/CONF.82/15, 28 I.L.M. 493; Council of Europe Convention on Laundering, Search, Seizure and Confiscation of the Proceeds of Crime, done in Strasbourg, 8 November 1990, 30 I.L.M. 148; United Nations Convention Against Corruption, done in Mérida and New York, 11 November 2003, 43 I.L.M. 37.

See Leonardo Borlini, 'Regulating Criminal Finance in the EU in the Light of the International Instruments', 36(1) Yearbook of European Law 553 (2017), at 557-559. 
implemented six directives and two regulations which are most relevant. The current framework, as it stands, consists primarily of the fourth ${ }^{52}$, fifth ${ }^{53}$, and $\operatorname{sixth}^{54}$ AML directives and the regulation on transfer of funds. ${ }^{55}$ In principle, EU's approach to money laundering has two main legs — criminalisation and prevention — which have evolved and which are intertwined. The intricate relationship between these two limbs is relevant for our study.

For a long time, there was no harmonised definition of what money laundering was on an EU scale. It is interesting to note that while the initial focus of EU's AML policy was on criminalisation, the first AML directive did not refer to money laundering as a crime: it merely stated that it was 'prohibited' ${ }^{56}$ Whereas the ultimate result of the first AML directive was that money laundering was 'de facto criminalized in all Member States', ${ }^{57}$ definitions were not harmonised. The underlying logic of this legislative choice by the EU legislator at the time was that criminal matters were a matter of national competence - with the Treaty of Lisbon of 2009, EU's policy on harmonisation in criminal law altered and there is now a legal basis for approximating substantive criminal law and rules of criminal procedure. ${ }^{58}$ Yet, the 'prohibition' rhetoric remained even in the fourth AML directive which was

52

Directive (EU) 2015/849 of the European Parliament and of the Council, OJ 2015 L 141/73.

53

Directive (EU) 2018/843 of the European Parliament and of the Council, OJ 2018 L 156/43.

54

Directive 2018/1673 of the European Parliament and of the Council, OJ 2018 L 284/22.

55

Regulation (EU) 2015/847 of the European Parliament and of the Council, OJ 2015 L 141/1.

\section{6}

Article 2 of Council Directive 91/308/EEC, OJ 1991 L 166.

See Borlini, above n 51, at 569.

On the limitations of harmonisation, see Kaie Rosin and Markus Kärner, 'The Limitations of the Harmonisation of Criminal Law in the European Union Protected by Articles 82(3) and 83(3) TFEU', 26 European Journal of Crime, Criminal law and Criminal Justice (2018), at 315-334. 
implemented after that in $2015^{59}$ — its legal basis is Article 114 TFEU (internal market) rather than Article and 83 TFEU (minimum definitions of criminal offences and sanctions). ${ }^{60}$

Whilst the fourth AML directive constitutes a significant step in remedying the uncertainty arising from the lack of common definition, ${ }^{61}$ scholars quickly noted that it blurred the lines between 'administrative and criminal law and sanctions' because it did not state 'what type and level of sanctions' were applicable for such acts. ${ }^{62}$ This problem was only partially remedied in the sixth AML directive whose transposition period still has not expired. ${ }^{63}$ Considering that late or incorrect transposition is a common problem for EU member states, this uncertainty still has not been conclusively resolved.

From a human rights perspective, such vagueness could have 'detrimental effects concerning procedural safeguards and fundamental rights protection'. ${ }^{64}$ Of course, the fact that there was no clear definition of what constituted money laundering and if the violation in question was of criminal or administrative nature seems to have affected the preventative leg of EU's AML policy too. ${ }^{65}$ In that light, it has been stressed that it was the third $\mathrm{AML}^{66}$ directive which introduced a more

See Article 1(2) of Directive (EU) 2015/849 of the European Parliament and of the Council, OJ 2015 L 141/73.

60

See the citations (preamble) of Directive (EU) 2015/849 of the European Parliament and of the Council, OJ 2015 L 141/73.

61

See Article 1(3) of Directive (EU) 2015/849 of the European Parliament and of the Council, OJ 2015 L 141/73 which defines money laundering.

62

Maria Bergstrom, 'The Many Uses of Anti-Money Laundering Regulation - Over Time and into the Future', 19 German Law Journal 1149 (2018), at 1154.

63

See Articles 5 and subsequent of Directive 2018/1673 of the European Parliament and of the Council, OJ 2018 L 284/22.

64

Bergstrom, above n 62, at 1167.

Borlini, above $\mathrm{n}$ 51, at 573 .

66

Directive 2005/60/EC of the European Parliament and of the Council, OJ 2005 L 309/15. 
palpable 'risk-based approach' ${ }^{67}$ Such preventative measures generally require regulated financial institutions to enquire about the origins of large amounts of cash that are being placed (what is known as 'Know Your Client' in finance) and to report any suspicious transactions to Financial Intelligence Units (FIUs) in member states. The FIUs also exchange information via the FIU.net system. ${ }^{68}$

In a nutshell, this preventative limb of EU's AML programme rests on three pillars: ${ }^{69}$ 1) the AML supervisors who oversee the implementation of the framework by regulated financial institutions and other entities; 2) the FIUs whose role is to analyse and/or investigate suspicious transactions; 3) law enforcement institutions which have powers to prosecute. It is in the interaction between these three pillars that we see that the lack of a common understanding of what exactly constitutes money laundering is not the only challenge. Namely, the compromised independence of FIUs and AML supervisors may also jeopardize the goals of AML legislation.

Although FIUs are supposed to be 'operationally independent and autonomous', ${ }^{70}$ a survey of FIU architecture in the EU raises concerns if this is the case. ${ }^{71}$ In ten countries they operate under government ministries. ${ }^{72}$ In one country (Italy), the FIU is under the central bank, while in another it is part of the tax authority (Hungary). Yet in another one, it is under the intelligence agency (Bulgaria), while in many EU members it is under a law enforcement authority. ${ }^{73}$ When it comes to AML

\section{7}

Bergstrom, above n 62, at1160.

68

Currently, cooperation between national FIUs is governed by Articles 51-57 of Directive (EU) 2015/849 of the European Parliament and of the Council, OJ 2015 L 141/73.

69 For a detailed overview, see Joshua Kirschenbaum and Nicolas Véron, 'A Better European Union Architecture to Fight Money Laundering', Bruegel, https://www.bruegel.org/2018/10/a-better-european-union-architecture-to-fightmoney-laundering/ 2018, accessed 25 March 2020.

70

Article 32(3) of Directive (EU) 2015/849 of the European Parliament and of the Council, OJ 2015 L 141/73.

71

See Kirschenbaum and Véron, above n 69.

72

Belgium, Croatia, Czech Republic, France, Germany, Lithuania, Luxembourg, Poland, Slovakia and Slovenia.

73 Kirschenbaum and Véron, above n 69. 
supervision of banks, in 15 countries it is the responsibility of the national central bank while in the rest it is under a separate financial conduct authority. ${ }^{74}$ Thus, more than half of the central banks in the EU have AML responsibilities.

Although different structures can work equally well in different contexts, what is critical is the extent to which the authorities can operate independently of governments and politics. In principle, banks are in a good position to determine if a transaction is legitimate. If they determine a transaction is suspicious, they have an obligation to report it to the authorities. However, some of them are negligent in applying these rules. They could be complicit too. This is precisely the area in which AML supervisors have a key role to play and this is where we may see the negative impact of compromised central bank independence, as we elaborate in the next section. Where failings do occur, the EU has a second line of defence, at least in theory. The European Banking Authority (EBA) has the power to investigate breaches of EU law, in which case it can override national authorities. ${ }^{75}$ In practice, however, one of the rare cases in which the EBA intervened was the mishandling of Pilatus Bank in Malta by the Maltese FIU, which we examine in the next section.

Finally, it should be noted that compromised independence of the FIU or the AML regulator does not just have negative implications for the country in which they are based because the most sophisticated examples of money laundering involve multiple jurisdictions. Literature on the specifics of money laundering describes it as a three-stage process: ${ }^{76}$

1) placement: illegitimate funds are placed in the banking system through financial institutions, casinos, shops, exchange bureaus or other legitimate businesses that are known to handle large amounts of cash without raising suspicions (e.g. restaurants or taxi companies) $;^{77}$

74 Ibid.

75 See Article 17 of Regulation 1093/2010 of the European Parliament and of the Council, OJ 2010 L 331. 76

Dennis Cox, Handbook of Anti Money Laundering (Chichester: Wiley \& Sons, 2014) 14.

77

Ibid, at 15-17. 
2) layering during which the origin of the money is disguised, often through multiple transactions $;^{78}$

3) integration which involves re-introducing laundered funds into the legitimate economy. ${ }^{79}$

Because of the single market, each of the stages can be performed in different jurisdictions.

\section{Central Bank Independence and Standards of Governance}

In this section we rely on published sources and unique personal insights to demonstrate that the independence of national central banks and/or other AML supervisors in five smaller member states has been eroded since 2013. To this end, we provide evidence from Cyprus, Latvia, Slovakia and Slovenia suggesting that central bank independence has weakened. In three of these cases (Cyprus, Slovakia and Slovenia), the central bank has direct AML responsibilities. It is plausible to expect that the erosion of central bank (or other AML supervisors') independence can weaken AML defences. A mechanism through which this can happen is through intentional under-resourcing of the AML supervision function, as we explain below. It can also happen more directly through covert pressures exerted on AML supervisors by politicians, but this is, by definition, much harder to detect. In addition, we analyse AML weaknesses in Malta, the smallest member state, in the case of its supervision of Pilatus Bank. ${ }^{80}$

Money laundering and, more generally, illicit financial flows are, of course, not confined to the smaller member states. There have been scandals involving banks at the core of the EU, including Germany and the UK. ${ }^{81}$ Scandals have also escalated

78

Ibid, at 17-18.

79

Ibid, at 18-19.

80 Recommendation to the Maltese Financial Intelligence Analysis Unit (FIAU) on Action Necessary to Comply with the Anti-Money Laundering and Countering Terrorism Financing Directive, 11 July 2018, EBA/REC/2018/02.

81 In 2017, seventeen banks based in the UK/with branches in the UK were implicated in the 'Global Laundromat' scandal which also engulfed Deutsche 
in Sweden and Denmark - countries with traditionally strong institutions. ${ }^{82} \mathrm{We}$ would, however, argue that smaller states, especially those with geographical or political ties to Russia, are the Achilles heel of the EU at the placement stage of the money laundering process, while the core countries often tend to be the targets for the final stage of the process - when the money is integrated into the financial system and can be used as if its origins are legitimate. The entry point is, however, critical. Once dirty money enters the single financial market, it can move relatively freely across member states.

AML supervisors in small member states with large banking systems are particularly vulnerable to capture by powerful financial interests, as are the media and state institutions. In the case of Cyprus, we document the erosion of central bank independence and argue that this had a direct impact on AML prevention capabilities through under-resourcing of the AML supervision function. Cyprus is not, however, unique when it comes to the undermining of central bank independence. Other countries that had similar experiences include Latvia, Slovakia and Slovenia. In Latvia the violation of central bank independence was, in fact, confirmed by the Court of Justice of the European Union (CJEU), as we discuss below. ${ }^{83}$ In the other three cases, the compromised independence of the central bank can be deduced by the resignation of their respective governors before the end of their term. One of the

Bank. See Luke Harding, Nick Hopkins and Caelainn Barr, 'British Banks Handled Vast Sums of Laundered Russian Money', The Guardian, https://www.theguardian.com/world/2017/mar/20/british-banks-handled-vastsums-of-laundered-russian-money (accessed 14 April 2020), Luke Harding, 'Deutsche Bank Faces Action Over \$20bn Russian Money-Laundering Scheme', The Guardian, https://www.theguardian.com/business/2019/apr/17/deutsche-bankfaces-action-over-20bn-russian-money-laundering-scheme, accessed 14 April 2020; In 2019, UK's Financial Conduct Authority imposed a fine of $£ 102,163,200$ On Standard Chartered Bank for poor AML controls. See Press Release of 9 April 2019, https://www.fca.org.uk/news/press-releases/fca-fines-standard-charteredbank-102-2-million-poor-aml-controls, accessed 14 April 2020.

82 The Danske Bank scandal has been termed '[Europe's] largest known money laundering scheme'. In the period 2007-2015, \$230 billion was allegedly laundered through non-resident accounts at Danske Estonia. See Raggett, above n 16; In 2020, Swedbank was fined by Sweden's Financial Supervisory Authority for weak AML controls. See Richard Milne, 'Swedbank Fined \$400m Over Weak MoneyLaundering Controls', Financial Times, 19 March 2020.

83 CJEU, Joined Cases C-202/18 and C-238/18, Ilmārs Rimšēeičs and ECB v Latvia (2019). 
standard indicators used by the economics literature to establish the degree of de facto central bank independence is whether governors serve their full-term. ${ }^{84}$

\section{A. Cyprus}

Cyprus is a country that has frequently been implicated in alleged money laundering scandals. ${ }^{85}$ The broader picture is one in which the Cypriot banking system doubled in size during 2005-10, partly due to the influx of Russian and Ukrainian funds into the island's banks, facilitated by politically connected Cypriot law firms. At the end of 2011 , the country's two largest banks suffered losses amounting to $25 \%$ of the country's Gross Domestic Product (GDP) as a result of the Greek crisis. ${ }^{86}$ As the Cypriot government was unable to bail them out without external financial assistance, it was forced to apply for an EU/International Monetary Fund (IMF) bailout in June 2012. Part of the economic adjustment programme involved strengthening AML supervision. ${ }^{87}$ The weakness in that area was seen as the primary cause of the bloated banking system by Cyprus' international creditors. However, in Cyprus itself the ruling elite not only persuaded the general public that allegations of money laundering by Cyprus' international creditors was a conspiracy to destroy the banking system, but it also managed to shift blame for the crisis to the central bank and its Governor for allegedly exaggerating the losses of the banks and/or providing the weapon of

Alex Cukierman, Central Bank Strategy, Credibility and Independence, (Cambridge: MIT Press, 1992) 445-454.

85 See Jacob Barron, 'Don't Be Cyprus: Basic Money Laundering Compliance in the Wake of a Punishing Bailout', Business Credit, June 2013, at 4-5; Paul Manafort, the lobbyist who ran Donald Trump's election campaign, was indicted for fraud for channeling millions through countries like Cyprus. See United States v Manafort, 1:18 Cr. 83 (TSE)(S-1), https://www.justice.gov/file/1038391/download, accessed 14 April 2020.

86 Sofronis Clerides, 'The Collapse of the Cypriot Banking System: A Bird's Eye View', 8(2) Cyprus Economic Policy Review 3 (2014) at 31.

87 See Economic and Financial Affairs, 'Ex-Post Evaluation of the Economic Adjustment Programme. Cyprus, 2013-2016', Institutional Paper 114, 18 October 2019, at 30 . 
blackmail to the ECB by supplying emergency loans to the banks during political negotiations. ${ }^{88}$

The government of Nicos Anastasiades, who was elected President of Cyprus in 2013, made it no secret that it was determined to limit the central bank Governor's powers or force him to resign - experts have deemed that the environment at the time was 'toxic'. ${ }^{89}$ Unsurprisingly, Anastasiades' party, the Democratic Rally (DYSI), (please insert full name of the party and abbreviation within parantheses) DYSI tabled controversial amendments to the Central Bank of Cyprus (CBC) laws. Thus, in April 2013, the ECB received a request for an opinion on these proposed amendments by the President of the House of Representatives in Cyprus. ${ }^{90}$ The main purpose of the draft law was to modify the composition of the CBC's Board of Directors by providing for seven directors instead of five, in addition to the Governor and Deputy Governor. $^{91}$ The two new director posts would be executive directors, while the remaining five would remain non-executive. ${ }^{92}$ The draft law also provided for an increase in the number of annual mandatory meetings of the Board from six to twelve and made the licensing of banking institutions and amendments to existing banking licenses subject to Board approval, shifting, in effect, licensing powers from the Governor to the Board. ${ }^{93}$ In addition, the draft law stipulated that the Board - and not the Governor - would assign specific duties to the executive directors who would be employed on a full-time basis. ${ }^{94}$ The proposed amendments also included a provision enabling the Government to set the terms of service of board members and their remuneration at the time of appointment. ${ }^{95}$

88

Demetriades, A Diary of the Euro Crisis in Cyprus: Lessons for Bank Recovery and Resolution, above n 11, 57-60.

89 See 'The Departure of Cyprus Central-Bank Governor: A Blow Against Independence', The Economist, 10 March 2014; Lesetja Kganyago, 'Principled Agents: Reflections on Central Bank Independence', Speech at the $19^{\text {th }}$ Annual Stavros Niarchos Foundation Lecture, Peterson Institute for International Economics, 15 April 2019.

90 Opinion of the ECB of 5 June 2013 on changes to the governance of the Central Bank of Cyprus, CON/2013/41, at introduction.

91 Ibid, at paragraph 1.1 .

92 Ibid.

93 Ibid, at paragraphs 1.3 and 1.5

94 Ibid, at paragraph 1.6.

95 Ibid, at paragraph 1.2 
ECB's Opinion CON/2013/41 in response to the request expresses serious concerns that the amendments would jeopardize the independence of the Governor and would interfere with the CBC's decision-making powers. ${ }^{96}$ The ECB stated:

'unless the executive directors and board members of a national central bank (NCB) are subject to the same legal requirements and enjoy the same independence safeguards of the $\mathrm{NCB}$ concerned, any provision assigning ESCB-related tasks of the Governor to an executive director, or requiring the approval of the NCB's Board for decisions of the Board, raises concerns about the Governor's ability to independently carry out the ESCB-related tasks assigned for the Governor. This would not be compatible with Article 130 of the Treaty and Article 7 of the Statute...'97

Furthermore, the ECB stressed that it 'consider[ed] that the draft law [was] unclear with regard to the nature of the executive directors' powers and the division of competences between the Board and the Governor' and express[ed] concern that 'without clarity in these respects...the CBC's decision making powers [would] be undermined'. ${ }^{98}$ The ECB also urged the consulting authority to 'take appropriate steps in order to preserve the independence of the $\mathrm{CBC}$ and the members of the decisionmaking bodies involved in the performance of ESCB-related tasks' ${ }^{99}$

Despite this compelling criticism, the Cypriot parliament enacted the proposed amendments in August 2013. Shortly after, the government put forward new controversial amendments seeking to further undermine central bank independence. Thus, the ECB issued a new Opinion in November 2013. ${ }^{100}$ These new amendments were intended to further limit the range of decisions that could be taken by the Governor, in effect shifting powers to CBC's Board. In an unusual step, this Opinion refers to the ECB's previous Opinion quoted above. The ECB was concerned that 'a number of observations made in that Opinion were not taken into account' and invited

96 Opinion of the ECB of 5 June 2013 on changes to the governance of the Central Bank of Cyprus, CON/2013/41.

97 Ibid, at paragraph 2.2.

98 Ibid, at paragraph 2.3.

99 Ibid, at paragraph 2.7.

100 Opinion of the ECB of 22 November 2013 on changes to decision-making powers at the Central Bank of Cyprus, CON/2013/78. 
'the relevant Cypriot authorities to address them'. ${ }^{101}$ It goes on to explain that the ECB also stressed that the amendments were not compatible with Article 130 TFEU and that the 'powers granted to the two executive directors and the governance structure's compliance with the requirement of central bank independence still need[ed] to be clarified' ${ }^{102}$

CBC Governor Panicos Demetriades resigned on 10 April 2014 - three years before the end of his term. In his letter of resignation, he stated that part of the reason for his resignation was difficulties working with the CBC Board. ${ }^{103}$ The government proceeded to appoint a Governor who was, arguably, more easily influenced. Evidence for this was provided by a judicial enquiry into the failure of the Cyprus Cooperative Bank, which had been bailed out with taxpayers' money in 2013. ${ }^{104}$ The bank failed in June 2018 partly because of its own governance failures, which the inquiry ascribed to its mishandling by the Cypriot minister of finance. The inquiry also revealed a letter from the central bank Governor to the President of Cyprus dated 23 October 2017 — months before a looming presidential election — in which the Governor boasted for preventing 'early intervention measures by the Single Supervisory Mechanism (SSM)'. ${ }^{105}$ This enabled the President to continue claiming that the Cyprus Cooperative Bank was healthy during the pre-election period. Had the SSM taken such early intervention measures, the government's mishandling of the bank could have cost the president his re-election in February 2018.

What is important to clarify is that the board, through its control of central bank resourcing, can be a genuine mechanism for limiting the independence of an NCB and curtailing the ability of a central bank Governor to act independently. This is because boards are normally responsible for the approval of central bank budgets, including staffing. A central bank board can, in effect, decide the extent to which all central bank functions, including AML supervision, can be resourced. The CBC's resourcing of its AML supervision function, for example, at the time of writing

\footnotetext{
$101 \quad$ Ibid, at paragraph 4.

102 Ibid.

103 Demetriades, A Diary of the Euro Crisis in Cyprus: Lessons for Bank Recovery and Resolution, above n 11, at 177.

104 Demetriades, Central Bank Independence and the Future of the Euro, above n 2 , at 87-88 and references therein to the Judicial Inquiry by George Arestis. 105 Ibid.
} 
remains inadequate. The latest MONEYVAL report on Cyprus, ${ }^{106}$ states that although the quality of supervision by the CBC (and the Cyprus Securities Exchange Commission which supervises non-bank financial institutions) is very good, 'shortfalls in staff resources are limiting the volume of supervision, linked with work on risk assessment, and sanctioning that can be taken'. ${ }^{107}$

\section{B. Latvia}

On 26 February 2019 the CJEU annulled the decision of Latvian authorities taken on 18 February 2018 suspending the Governor of the Central Bank of Latvia Ilmārs Rimšēvičs from office and imposing a prohibition to perform his duties as Governor, an obligation to pay a surety and an interdiction on leaving the country without prior authorisation. ${ }^{108}$ These measures were temporarily imposed on the Governor in the context of a preliminary criminal investigation concerning acts of bribery and corruption which the Governor was suspected of committing. The Court notes that although 'it may be necessary to suspend [the governor] temporarily from office' for the purpose of such an investigation, the Court has the power to verify that such a decision is taken only if there are 'sufficient indications that he has engaged in serious misconduct capable of justifying such a measure'. ${ }^{109}$ The Court held: 'Latvia has not established that the relieving of Mr. Rimšēvičs from office is based on the existence of sufficient indications that he has engaged in serious misconduct...'. ${ }^{110}$

What is of interest is that the corruption allegations against the central bank Governor and the decision of Latvia to suspend him from his duties was made amidst a money-laundering scandal, which led to the failure of ABLV, the third largest bank

106 Fifth Round Mutual Evaluation Report on Cyprus, December 2019, MONEYVAL(2019)27.

107 Ibid, at paragraph 29.

108 Ilmārs Rimševvičs and ECB v Latvia, above n 8381. This does not seem to eorrespond to footnote 81 ? The full citation of the case is needed.

109 Ibid, at paragraphs 91 and 92.

$110 \quad$ Ibid, at paragraph 96. 
in Latvia. ${ }^{111}$ Specifically, on 13 February 2018, the US Department of the Treasury's Financial Crimes Enforcement Agency (FINCEN) published a finding pursuant to Section 311 of the USA Patriot Act, seeking to prohibit the opening or maintaining of a correspondent account in the US by ABLV bank. ${ }^{112}$ FINCEN proposed this measure based on its finding that ABLV bank was a financial institution of 'primary money laundering' concern operating outside the US. ${ }^{113}$ FINCEN claimed that ABLV was used to 'facilitate money laundering, illicit financial schemes and other illicit activity conducted by its customers and other illicit actors, including actors associated with North Korea's procurement or export of ballistic missiles, sanctions evasion and large-scale corruption'. ${ }^{114}$ Although FINCEN's allegations were never proven in a court of law, its actions meant that ABLV could no longer access the US financial system. The consequence of the US measures was to cause reputational damage to ABLV that triggered a bank run and hindered its ability to obtain liquidity from the market. ${ }^{115}$ The liquidity pressures were so large that the bank was eventually deemed as failing or likely to fail (FOLTF) by the ECB. ${ }^{116}$ On 28 February 2018, the Single Resolution Board (SRB) concurred with ECB's assessment. ${ }^{117}$

The failure of ABLV exposed a glaring weakness in EU's AML institutional framework. The EU was not in a position to independently verify or refute the allegations made by FINCEN due to the lack of an EU-wide AML supervisor. If one accepts the US allegations as valid, one can only conclude that the Latvian AML supervisor was totally ineffective. However, in Latvia this responsibility lies within the Financial and Capital Markets Commission - not the central bank. ${ }^{118}$ Indeed,

111 See Silvia Marler, 'Latvia's Money Laundering Scandal', Bruegel, https://www.bruegel.org/2018/04/latvias-money-laundering-scandal/ 2018, accessed 8 April 2020.

112 See US Federal Register, Vol. 83, No. 33, Friday, February 16, 2018, 69866994.

113 Ibid, at 6986.

114 Ibid, at 6990.

115 See ECB's Non-Confidential Assessment of 23 February 2018, https://www.bankingsupervision.europa.eu/ecb/pub/pdf/ssm.2019_FOLTF_assess ment_ABLV_Bank_AS 48046b4adb.en.pdf, accessed 27 March 2020.

116 Ibid.

117 See Press Release by the SRB of 28 February 2018, https://srb.europa.eu/en/node/495, accessed 25 March 2020.

$118 \quad$ Kirschenbaum and Véron, above n 69. 
reports suggest that the AML supervisor was under-resourced. ${ }^{119}$ The ease with which, at the same time, the central bank Governor was suspended can only indicate that the Latvian authorities' actions were driven by political objectives rather than the respect for the independence of regulators. It is certainly suspicious that Latvian authorities took drastic action against the central bank Governor even though the central bank has no AML responsibilities - this may be interpreted as an attempt to create a smoke screen and hide the deeper causes of this crisis. This raises concerns about the independence of both the central bank and the AML supervisor. The European Commission - whose responsibility is to serve as the Guardian of the Treaties - remained silent throughout the whole affair. It was the ECB, in fact, that was a joint applicant with the Latvian central bank Governor in the case against Latvia at the CJEU. ${ }^{120}$

\section{Malta}

On 11 June 2018, the EBA issued a Recommendation addressed to the Maltese Financial Intelligence Unit (FIAU) after establishing that it had breached EU law in relation to its supervision of Pilatus Bank. ${ }^{121}$ The Recommendation is aimed at remedying the failings identified by the EBA by encouraging the FIAU to comply with the third AML directive. ${ }^{122}$ This was the first ever investigation by the EBA of a national competent authority's compliance with an AML directive and it followed a request by the European Commission to investigate a breach of EU law - it may not be coincidental that the Commission's request was issued shortly after the brutal murder of journalist Daphne Caruana Galizia who was investigating the dealings of Pilatus Bank and its connections to Malta's political elite, which raises many ethical

119 The MONEYVAL report on Latvia from 2018 raises concern that issues such as understanding the nature or significance of ML/FT risks, or a lack of knowledgeable resources, prevented the supervisory authorities from fully implementing programs focused on higher-risk market segments'. See Fifth Round Mutual Evaluation Report on Latvia, July 2018, MONEYVAL(2018)8, at 7.

$120 \quad$ Ilmārs Rimšēvičs and ECB v Latvia, above $\mathrm{n} 83$.

121 Recommendation to the Maltese Financial Intelligence Analysis Unit (FIAU), above $\mathrm{n} 80$.

122 Directive 2005/60/EC of the European Parliament and of the Council, OJ 2005 L 309/15. 
questions regarding the events which need to take place to launch such an inquiry as well as regarding the protection of whistleblowers. ${ }^{123}$ The EBA investigation revealed that the FIAU failed to conduct an effective supervision of Pilatus Bank in relation to its AML obligations due to a number of failures, including procedural deficiencies and lack of supervisory actions and sanctions. ${ }^{124}$

Specifically, the EBA announced that it found 'general and systematic shortcomings' in Malta's application of AML rules. ${ }^{125}$ It is, therefore, plausible that Pilatus Bank was not the only AML failure in Malta, although by itself this was a major scandal involving politicians and culminating with the murder of Caruana Galizia, Our conclusion is reinforced by the fact that the latest MONEYVAL report on Malta explicitly states that " $[\mathrm{t}]$ he supervisory authorities do not have adequate resources to conduct risk-based supervision, for the size, complexity and risk profiles of Malta's financial and [Designated Non-Financial Businesses and Professions sector] ${ }^{126}$ - a similar problem observed in Cyprus. In principle, Pilatus' chairman, Iranian national Ali Sadr Hashemi Nejad, was arrested in the US in March 2017 on suspicion that he had funneled US \$115 million through US banks, violating US sanctions against Iran. ${ }^{127}$ Pilatus Bank had its license withdrawn by the ECB in November 2018. ${ }^{128}$

123 Recommendation to the Maltese Financial Intelligence Analysis Unit (FIAU), above $\mathrm{n}$ 80, at paragraph 6; The Commission requested an investigation only in October 2017 - the month of Caruana Galizia's murder; See also Dimitrios Kafteranis, 'The Pilatus Bank Scandal: Time to Reconsider Banking Supervision, Anti-Money Laundering and Whistle-Blower's Protection in the EU', European Law Blog, https://europeanlawblog.eu/2018/12/05/the-pilatus-bank-scandal-timeto-reconsider-banking-supervision-anti-money-laundering-and-whistle-blowersprotection-in-the-eu/ (accessed 8 April 2020).

124 See Recommendation to the Maltese Financial Intelligence Analysis Unit (FIAU), above $n$ 80, at paragraphs 13-18.

125 Ibid, at paragraph 19.

126 Fifth Round Mutual Evaluation Report on Malta, July 2019, MONEYVAL(2019)5, at 7.

127 Matthew Vella, 'US Arrests Pilatus Bank Chairman over Alleged \$115 Million Sanctions Evasion Scheme', The Times of Malta, https://www.maltatoday.com.mt/news/world/85450/us_arrests_pilatus_bank_chair man_over_alleged_115_million_sanctions_evasion_scheme\#.Xo8viUBuKUk, 2018, accessed 9 April 2020.

128 Statement by the Malta Financial Services Authority, November 2018, https://www.mfsa.com.mt/pages/readfile.aspx?f=/files/ 


\section{Other Member States}

The independence of central banks seems to be under a threat in other EU member states, too. In Greece and Portugal, central banks and their governors were blamed for bank failures and were subjected to political pressure, including attempts to force them to resign. ${ }^{129}$ In Slovakia, the central bank Governor Josef Makúch was forced to leave office before the end of his term in 2018: media reports suggest that he stepped down in order to avoid friction with the Slovakian government which wanted to replace him. ${ }^{130}$ The circumstances behind the resignation of the central bank Governor of Slovenia Boštjan Jazbec seem to showcase more clearly the perverse effects of pressure. In 2016, the central bank of Slovenia was raided by the police and prosecution which seized materials - a development which urged then President of the ECB Mario Draghi to 'formally protest against such unlawful seizure of ECB information'. ${ }^{131}$ Subsequently, the Governor resigned in 2018 after receiving death threats which he linked to his role in addressing a banking crisis in 2013-2014. ${ }^{132}$ Slovenia's central bank had imposed losses on retail investors in banks which failed at

Announcements/PressReleases/2018/MFSA\%20PR\%2030\%20June\%20Pilatus.pdf , accessed 8 April 2020.

129 Peter Wise, 'Political Storm Hits Portugal's Central Bank Chief Carlos Costa', Financial Times, https://www.ft.com/content/320cb516-d700-11e5-888798e7feb46f27, accessed 14 April 2020; In Greece, authorities raised charges against the central bank Governor and raided the offices of his wife. Subsequently, all charges were dropped. The Governor said he was the victim of a 'character assassination plot'. See Dan Hardie, 'Greek Authorities Drop Corruption Probe into Governor', Central Banking, https://www.centralbanking.com/centralbanks/governance/4403241/greek-authorities-drop-corruption-probe-into-governor, accessed 14 April 2020.

130 'Slovak Governor Resigns Early as Politicians Express Interest in Job', Central Banking,

https://www.centralbanking.com/central-banks/governance/3905726/slovakgovernor-resigns-early-as-politicians-express-interest-in-job, accessed 10 April 2020.

131 See Letter by Mario Draghi to State Prosecutor General of the Republic of Slovenia, 6 July 2016, L/MD/16/345,

https://www.ecb.europa.eu/pub/pdf/other/160706letter_fiser.en.pdf, accessed 10 April 2020.

132 Press Release by the Central Bank of Slovenia, 20 March 2018, https://www.bsi.si/en/media/1205/press-release, accessed 10 April 2020. 
the time. In fact, the Slovenian context seems similar to the Cypriot one discussed above because investors in both countries claimed that the central bank had exaggerated the banks' losses and were able to gather sufficient political support to exert pressure on their central bank Governors.

\section{E. Broader Governance Weaknesses}

The undermined central bank independence in the Euro-area member states examined above is significant by itself. However, it is also plausible — indeed likely — that other central bank governors are changing their behaviour to comply with the wishes of their respective governments in order to avoid political pressures or unpleasantries. Whether such realignment has a material impact on bank supervision, resolution and AML supervision merits further research, but surely the cases discussed above raise concerns that this is probable. Unfortunately, these are very delicate issues which can primarily be exposed by whistleblowers, such as former employees of central banks or investigative journalists, who, in turn, may risk their lives, as we saw above in the case of Caruana Galizia.

The EU countries in which the AML supervision is in the hands of central banks are as follows: Bulgaria, Croatia, Cyprus, Czech Republic, France, Greece, Hungary, Ireland, Italy, Lithuania, Netherlands, Portugal, Romania, Slovenia and Slovakia. ${ }^{133}$ If the erosion of central bank independence, or independence of AML supervisors at large, takes place in countries with weak or weakening governance standards, any weakness in AML supervision can be amplified. Indeed, standards of governance in the EU vary widely. EU-27 includes countries such as Denmark that have among the highest standards in the world - although Denmark was also recently plagued by a money laundering scandal involving Danske Bank's Estonian operations as we mentioned above - and Bulgaria whose governance standards are more typical of developing countries. ${ }^{134}$

133 Kirschenbaum and Véron, above n 69.

134 See the interactive data on the website of the Worldwide Governance Indicators, https://info.worldbank.org/governance/wgi/Home/Reports, accessed 8 April 2020. 
Tables 1 and 2 around here

Tables 1 and 2 provide a bird's eye view of two World Bank Governance Indicators - Rule of Law and Control of Corruption, respectively - for selected EU countries in 2013 and 2018. Besides showing considerable variation across countries, the tables also show remarkable deterioration in Cyprus and Malta from 2013 to 2018. They show disturbingly large declines in both the rule of law and control of corruption. It is important to note that Malta and Cyprus have legal systems that are predominantly based on the common law - they would normally be expected to have better functioning institutions than former-socialist countries, such as Estonia and Latvia. $^{135}$ Our conjecture - which should be a call for further research — is that the deterioration in governance in Cyprus and Malta is closely related to illicit financial flows connected to politics and may reflect weaknesses in AML implementation. It does not seem coincidental that these large declines were observed shortly after money laundering scandals evidencing compromised independence of AML regulators erupted, as we saw above.

The case of Cyprus warrants further analysis, not least because of the EU/IMF economic adjustment programme we mentioned above. Although this programme aimed to address AML weaknesses in the banking system by introducing a more effective compliance framework within commercial banks, it could not address deeper political economy factors - particularly the politically connected and powerful law and accountancy firms that form an integral part of the country's ruling elite, which made their money by serving the needs of wealthy Russians and Ukrainians. The latest MONEYVAL report on Cyprus in fact highlights remaining weaknesses outside the banking system that are connected to the Citizenship by Investment Scheme which allows foreign investors to acquire citizenship by purchasing newly built properties

135 See Rafael La Porta, Florencio Lopez-de-Silanes and Andrei Schleife, 'The Economic Consequences of Legal Origins', 46(2) Journal of Economic Literature (2008), 285-332. 
with a price tag of at least two million euros. ${ }^{136}$ The MONEYVAL report identifies the scheme as a high risk one for money laundering and pinpoints AML weaknesses in administrative service providers, including advocates and lawyers' companies that are integral to the scheme. ${ }^{137}$ Arguably, it is these types of companies, which helped wealthy non-resident clients set up Cyprus registered companies and acted as nominee shareholders, that were responsible for the influx of illicit financial flows into Cyprus prior to the 2013 crisis, although the banks were, of course, needed to process and facilitate these flows.

The 2013 crisis and the measures to strengthen AML implementation by banks did reduce money flows between Cyprus and Russia during the crisis and immediately afterwards. However, the Foreign Direct Investment (FDI) figures between Cyprus and Russia published by the Bank of Russia (portrayed in Figure 1) reveal that the decline was only temporary. According to these statistics, inward FDI stocks doubled from EUR 15.9 billion in 2008 - around 80\% of Cyprus GDP - to EUR 33.9 billion in 2017 - over $160 \%$ of GDP. The Bank of Russia has estimated that by October of 2019 Russian FDI stocks have reached $\$ 456$ billion - 31.4\% come from Cyprus. ${ }^{138}$ The inward FDI data from Bank of Russia does, in fact, suggest that a lot of the FDI from Cyprus may reflect 'round-tripping'. ${ }^{139}$ It appears that many wealthy Russians could be using Cyprus to hide their identity from state authorities and reinvesting their illicit funds back into Russia in a seemingly legal fashion. In any case, the same period more or less coincides — in our view not by accident - to the biggest decline in World Bank governance indicators experienced by any EU member state. ${ }^{140}$

136 Fifth Round Mutual Evaluation Report on Cyprus, December 2019, MONEYVAL(2019)27, at 4-5.

137 Ibid, at 16-17.

138 Dataset by the Bank of Russia, http://www.cbr.ru/vfs/statistics/credit_statistics/direct_investment/10-dir_inv.xlsx, accessed 14 April 2020.

139 On the concept of round-tripping, see Svetlana Ledyaeva, Päivi Karhunen, Riitta Kosonen and John Whalley, 'Offshore Foreign Direct Investment, Capital Round-Tripping, and Corruption: Empirical Analysis of Russian Regions', 91(3) Economic Geography (2015) 305-341.

140 Our worries about Cyprus are reinforced by the Compliance Report on Fourth Evaluation Round: Corruption Prevention in Respect of Members of Parliament, Judges and Prosecutors, GrecoRC4(2018)9, according to which Cyprus complied fully with only two and partially with only eight recommendations (out of sixteen) by GRECO. 
A concrete example which indicates that large money flows from Russia may foster corruption in the legal system and may import practices of kleptocratic regimes is the criminal conviction of the former Deputy Attorney General (AG) Rikkos Erotokritou for bribery and corruption in 2017. ${ }^{141}$ Erotokritou was sentenced to three and a half years in prison for conspiring with a private law firm to prosecute five Russian natural and legal persons involved in a civil court case related to a Cyprusbased trust fund that was in a dispute with other Russians over the ownership of assets valued 250-300 million euros. ${ }^{142}$ Erotokritou was a politician and a practicing criminal lawyer who actively supported the candidacy of Nicos Anastasiades during the 2013 presidential election. He was appointed to the post of Deputy AG by Anastasiades soon after the latter took office on 1 March 2013. Anastasiades backed Erotokritou during the trial and testified in Court as a defence witness. ${ }^{143}$ In principle, the Council of Europe's Group of States against Corruption (GRECO) has also raised concern that the Law Office of the Republic - the prosecution authority of Cyprus is not independent and needs safeguards to ensure autonomous exercise of duties. ${ }^{144}$

\section{Figure 1 around here}

To sum up, the independence of several national central banks and other AML supervisors within the euro area appears to have been eroded. Such erosion can easily translate into weaknesses in the effectiveness of the AML framework through underresourcing of AML supervision or other, more covert, means. Indeed, under-

141 Cyprus, Nicosia Criminal Court, Democracy v Rikkos Erotokritou et al, Case no 9208/15, 8 February 2017.

142 For a summary of the facts in English, see Sarah Fenwick, 'President Anastasiades Appears in Court as Defense Witness in Erotokritou Bribery Trial', Cyprus News Report, https://www.cyprusnewsreport.com/2016/06/presidentanastasiades-appears-court-defence-witness-erotokritou-bribery-trial, accessed 14 April 2020; Note that under Cypriot law, companies may bear criminal liability, which, in practice, leads to similar results as administrative sanctions under continental systems.

143 Ibid.

144 See Compliance Report on Fourth Evaluation Round: Corruption Prevention in Respect of Members of Parliament, Judges and Prosecutors, GrecoRC4(2018)9, at 11 . 
resourcing of AML supervisors is a common theme in some of the smallest EU members and has been identified by MONEYVAL as one of the key causes of weakness, as we explained above. It is also plausible that such weakness carries over to the enforcement capabilities — the events in Malta, where the FIU has both preventive and enforcement responsibilities, suggest that this is likely. Evidence of failure of AML regulators is hard to come by because of the sensitivity of these issues, but the cases of compromised central bank/AML supervisor independence discussed above surely raise Red Flags which merit future research.

\section{Concluding Remarks and Recommendations}

Smaller countries in the EU may be particularly vulnerable to illicit money flows due to the presence of powerful interest groups that use their political links to pressurise AML authorities. As AML regulators are often the national central banks, compromised central bank independence can have unintended consequences that go well beyond what the architects of the monetary union could have foreseen in the 1970s.

Thus, the erosion of central bank independence, where it occurs, creates additional systemic risks for the monetary union. Once laundered money enters the euro area - or the single EU market — it creates risks for all EU member states. The risks are wide-ranging. They include reputational costs to ESCB and ECB, but also possible financial instability since illicit financial flows can also result in bank failures, as in the ABLV case because of the actions taken by US authorities. In addition, as argued above, these illicit financial flows may often be tied to corruption, rule of law decay or malign activities undermining democracy, all of which underlie and promote European disintegration.

To mitigate these risks, the EU cannot always rely on national supervisors or national bodies to identify and hold money launderers or facilitators of illicit transfers accountable. Such transfers often involve multiple jurisdictions, so investigations require cooperation and coordination between national bodies. If the independence of national bodies is compromised, such cooperation is likely to be challenging — if the 
beneficiaries from illicit financial flows are high-ranking politicians, such cooperation is unlikely to be forthcoming. It is, therefore, vital to increase the powers of EU bodies such as the EBA and the SSM, so that they can oversee and coordinate the work of national bodies. ${ }^{145}$

The SSM is already supervising all banks in the euro area but has limited powers over AML supervision. It would only take a relatively modest amendment to the SSM regulation to assign additional powers for AML supervision. The EBA has limited powers to intervene whenever there are significant breaches of EU law; however, it neither has the resources nor the muscle to be an effective AML supervisor. At best, it can oversee the work of national supervisors in countries that are not members of the SSM.

In addition, AML supervision can become more effective if governance standards in national central banks and other AML supervisors are strengthened. To this end, the EU could consider introducing EU-wide fit and proper criteria for governing bodies of AML supervisors. As things stand, governments can appoint individuals to central bank governing bodies that would not meet the SSM's fit and proper criteria for non-executive directors of commercial banks (e.g. senior bankers whose banks failed or were fined for violating AML rules have been appointed to boards of national central banks). ${ }^{146}$

Prevention is of course necessary but cannot be sufficient on its own if the deterrent is ineffective. At the moment, the power to investigate and prosecute money laundering crimes remains primarily in the hands of national authorities, which is highly problematic given that prosecutors can come under political pressure, especially in countries with rule of law deficiencies. It is, therefore, essential to assign investigative, if not also, prosecution powers to a body such as Europol, or extend the mandate of the newly formed European Public Prosecutor's Office, so that crimes that are multi-jurisdictional can be adequately investigated and prosecuted at the EU level.

See also Kirschenbaum and Véron, above n 69. They consider a greater range of alternatives, including setting up a new AML body, which in our view would neither be the most efficient nor the fastest way to proceed.

146

Panicos Demetriades, 'Failing Banks, Bail-ins, and Central Bank Independence: Lessons from Cyprus', https://voxeu.org/article/bank-bail-ins-lessonscypriot-crisis 2018, accessed 26 March 2020. 
Even more so, when it comes to illicit financial flows intended to destabilise the EU.

Such flows can be a serious threat to the survival of the EU as a project for peace based on democracy and the rule of law. ${ }^{147}$

Figure 1. Russian Inward FDI Stocks in Cyprus

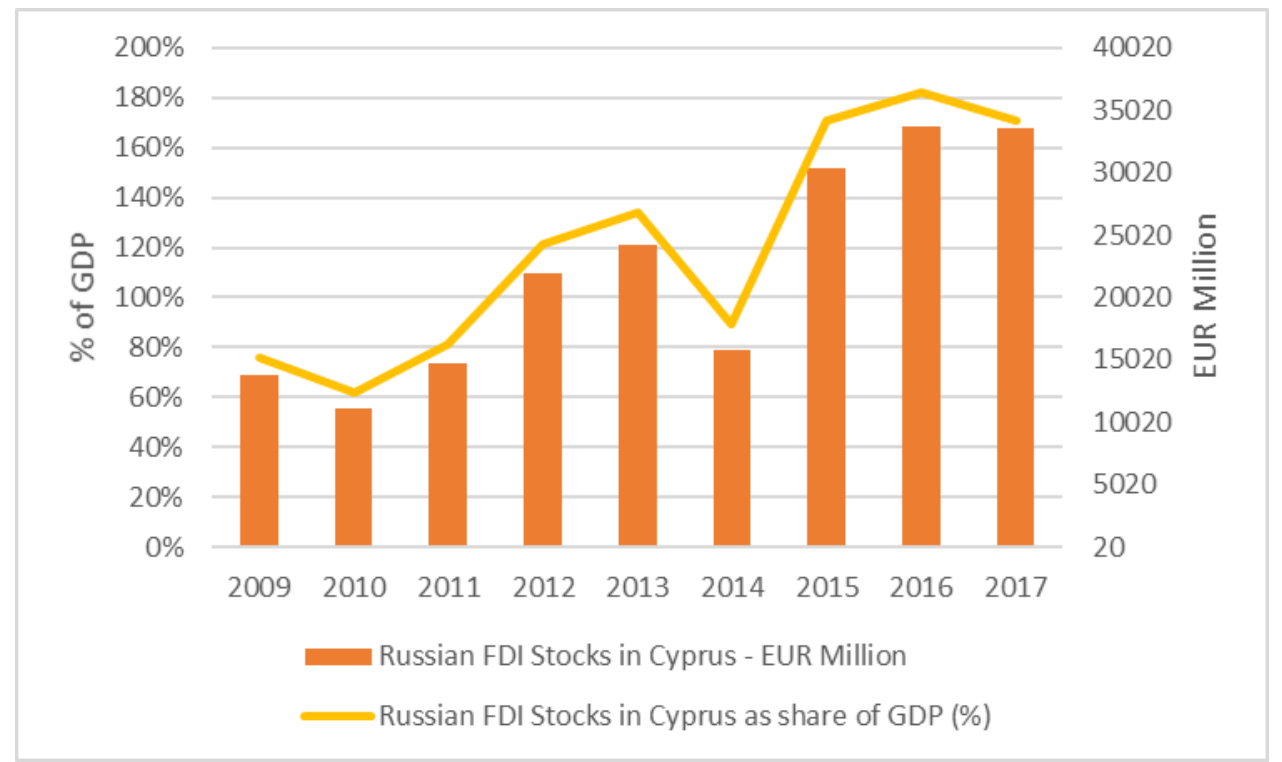

147

There are already official proposals in place to strengthen the EU's defences against money laundering. One is a proposal for a regulation by the European Commission published in 2018 which involves increasing the AML powers of the EBA to coordinate the work of national competent authorities and to intervene whenever there is weakness at the national level. See $\operatorname{COM(2018)} 646$ final; There is also a recent proposal by six member states. See Joint Position Paper by the Ministers of Finance of France, Germany, Italy, Latvia, the Netherlands, and Spain, https://www.tweedekamer.nl/kamerstukken/amendementen/detail?id=2019Z21663\&d $\mathrm{id}=2019 \mathrm{D} 45039$ (accessed 9 April 2020); The Commission's proposal is not dissimilar to ours, although it relies excessively on the EBA whose role and resources are not an ideal match with what is needed for an AML supervisor. The proposal by the six member states is problematic because it involves setting up a completely new EU body - this is neither the most efficient way to tackle the weakness nor the fastest. Moreover, neither of the two proposals addresses the weakness at national level — the notion that the EU supervisor will intervene whenever the national authority fails to act may challenge one of the most important principles of supervision - prompt and effective action. 
Source of data: Bank of Russia, https://www.cbr.ru/eng/statistics/macro_itm/svs/, accessed 20 March 2020.

TABLE 1

RULE OF LAW IN SELECTED EU COUNTRIES

\begin{tabular}{ll|l|l|l|l} 
& Estimate & Estimate & Rank & Rank & Sources \\
\hline Country & 2013 & 2018 & 2013 & 2018 & 2018 \\
\hline $\begin{array}{l}\text { Bulgaria } \\
\text { Cyprus }\end{array}$ & -0.10 & -0.03 & 52.11 & 53.37 & 13 \\
\hline $\begin{array}{l}\text { Denmark } \\
\text { Estonia }\end{array}$ & 1.04 & 0.75 & 82.16 & 75.96 & 9 \\
\hline $\begin{array}{l}\text { Germany } \\
\text { Latvia }\end{array}$ & 1.90 & 1.83 & 98.59 & 96.63 & 10 \\
\hline $\begin{array}{l}\text { Malta } \\
\text { Netherlands }\end{array}$ & 1.65 & 1.24 & 86.38 & 86.54 & 12 \\
\hline UK & 1.84 & 1.63 & 92.02 & 91.35 & 10 \\
\hline
\end{tabular}

Source of data: World Bank Governance Indicators 2019, https://info.worldbank.org/governance/wgi/Home/Reports, accessed 8 April 2020.

TABLE 2

CONTROL OF CORRUPTION IN SELECTED EU COUNTRIES

\begin{tabular}{ll|l|l|l|l} 
& Estimate & Estimate & Rank & Rank & Sources \\
\hline Country & 2013 & 2018 & 2013 & 2018 & 2018 \\
\hline $\begin{array}{l}\text { Bulgaria } \\
\text { Cyprus }\end{array}$ & -0.27 & -0.15 & 48.8 & 51.0 & 13 \\
\hline $\begin{array}{l}\text { Denmark } \\
\text { Estonia }\end{array}$ & 1.25 & 0.64 & 84.83 & 74.04 & 9 \\
\hline Germany & 1.40 & 2.15 & 100.0 & 98.56 & 9 \\
\hline $\begin{array}{l}\text { Latvia } \\
\text { Malta }\end{array}$ & 1.81 & 1.51 & 83.41 & 89.90 & 12 \\
\hline $\begin{array}{l}\text { Netherlands } \\
\text { UK }\end{array}$ & 0.33 & 0.33 & 66.82 & 64.42 & 11 \\
\hline
\end{tabular}


Source of data: World Bank Governance Indicators,

https://info.worldbank.org/governance/wgi/Home/Reports, accessed 8 April 2020. 